\title{
PENERAPAN ETIKA ADMINISTRASI NEGARA DALAM PELAYANAN KENAIKAN PANGKAT DI KANTOR BADAN KEPEGAWAIAN DAN DIKLAT DAERAH KABUPATEN GOWA
}

\author{
SUKRI J ${ }^{1}$, MUHAMMAD IDRIS ${ }^{2}$,BURHANUDDIN ${ }^{3}$ \\ 1)Mahasiswa Jurusan Ilmu Administrasi Negara Unismuh Makasssar \\ ${ }_{2}^{2}$ Dosen Jurusan Ilmu Administrasi Negara Unismuh Makassar \\ ${ }_{3}^{3}$ Dosen Jurusan Ilmu Administrasi Negara Unismuh Makassar
}

\begin{abstract}
The objective of this research was to obtain the application of the administration country ethic in the service of position improvement in the office of Badan Kepegawaian dan Diklat in Gowa regency. That was based on the government rule number 10 in 1979 about the employee job action measurement. The kind of the research used was the descriptive qualitative with the fenomenology type. The research informants were nine people with the deep interview, focus observation, and documentation as the data collecting technique. Besides, the data analysis qualitatively sistematic through data redcuction, data serving, verification and conclusion. The research result in the aplication of employee ethic codes showed that there were three things related, they were: loyalty, responsibility, and faithfully. Further, in the aplication of public ethic modality showed that there were three things related, they were: accountabilty, transparancy, and netrality.
\end{abstract}

Keywords: Ethics of Administration, Promotion Service

\begin{abstract}
ABSTRAK
Tujuan dari penelitian ini adalah untuk mengetahui penerapan etika administrasi Negara dalam pelayanan kenaikan pangkat di Kantor Badan Kepegawaian dan Diklat di Kabupaten Gowa. Hal ini sesuai dengan Peraturan Pemerintah Nomor 10 Tahun 1979 tentang Penilaian Pelaksanaan Pekerjaan Pegawai. Jenis penelitian yang digunakan deskriptif kualitatif dengan tipe penelitian fenomenologi. Informan penelitian berjumlah sembilan orang dengan teknik pengumpulan data menggunakan wawancara mendalam, observasi terfokus, dan dokumentasi. Sementara analisa data secara kualitatif dilakukan secara sistematis yakni reduksi data, penyajian data, verifikasi dan kesimpulan.. Hasil penelitian pada penerapan kode etik pegawai menunjukkan bahwa ada tiga yang terkait dalam hal tersebut yakni kesetiaan, tanggungjawab dan ketaatan. Sedangkan pada penerapan modalitas etika publik menunjukkan ada tiga hal yang terkait dalam hal tersebut yakni : akuntabilitas, transparansi dan netralitas.
\end{abstract}

Kata kunci: Etika Administrasi, Kenaikan Pangkat 


\section{PENDAHULUAN}

Merujuk pada pasal 4 dan 5 Undang Undang Nomor 5 Tahun 2014 tentang Aparatur Sipil Negara diantaranya menyebutkan bahwa para aparatur sipil negara harus menjunjung tinggi standar etika yang luhur. Selanjutnya dalam undang undang tersebut juga dinyatakan bahwa para pejabat publik harus mematuhi kode etik dan kode perilaku pegawai, diantaranya adalah: melaksanakan tugasnya dengan cermat dan disiplin, melayani dengan sikap hormat, sopan, dan tanpa tekanan, menjaga kerahasiaan yang menyangkut kebijakan negara.

$$
\text { Masalah etika dalam }
$$
birokrasi menjadi keprihatinan (concern) yang sangat besar, karena perilaku birokrasi mempengaruhi bukan hanya dirinya, tetapi masyarakat banyak. Di samping itu birokrasi bekerja atas dasar kepercayaan, karena seorang birokrat bekerja untuk negara dan berarti juga untuk rakyat . Jadi wajar jika rakyat mengharap adanya jaminan bahwa Para birokrat yang dibiayai oleh negara harus mengabdi kepada kepentingan umum menurut standar etika yang selaras dengan kedudukannya.

Kata etik berarti kumpulan asas atau nilai yang berkenaan dengan akhlak atau nilai mengenai benar dan salah yang dianut suatu golongan atau masyarakat. Adapun kata etiket berarti tata cara atau adat, sopan santun dan lain sebagainya dalam masyarakat beradaban dalam memelihara hubungan baik sesama manusia (Haris, 2007: 3)

Kenyataan yang terjadi pada pelayanan kenaikan pangkat di Badan Kepegawaian dan Diklat Daerah (BKDD) Kabupaten Gowa tentang penerapan etika administrasi negara masih jauh dari nilai ideal yang ada.

Realitas menunjukan bahwa pemerintah tidak menerapkan kode etik kepegawaian secara memadai. Asumsi bahwa semua aparat pemerintah adalah pihak yang telah teruji pasti selalu membela kepentingan publik, tidak selamanya benar. Banyak kasus membuktikan bahwa kepentingan pribadi, keluarga, kelompok, partai dan bahkan struktur yang lebih tinggi justru mendikte 
perilaku seorang birokrat atau aparat pemerintahan.

Masalah yang sering dihadapi pada penerapan kode etik kepegawaian yang ada di daerah ini adalah kurangnya mematuhi kode etik mengenai disiplin pegawai dalam memberikan pelayanan. Dimana melalui hasil observasi awal ditemukan pegawai yang sering datang terlambat sehingga pelayanan kenaikan pangkat yang ada menjadi terhambat.

Hal ini tentunya tidak baik untuk pelaksanaan pelayanan tersebut. Pegawai dari institusi lain yang mengurus kenaikan pangkatnya juga sering mengeluhkan hal ini. Selain itu juga ditemukan kasus tanggung jawab dimana terdapat kurang cermatnya pegawai di kantor dalam memberikan pelayanan kenaikan pangkat.

Pegawai tersebut kurang cermat dalam menata dokumen, surat, atau catatan tertentu yang diperlukan dalam proses pelayanan kenaikan pangkat. Sehingga ketika dokumen tersebut diperlukan pegawai tersebut selalu sibuk mencari dokumen dan terkesan tidak praktis. Hal ini membuat orang yang memerlukan pelayanan tersebut menunggu lama dikarenakan dokumen yang ada sering tercecer.

Hal di atas tentunya tak sesuai pula dengan Peraturan Pemerintah Nomor 46 Tahun 2011 Tentang Penilaian Prestasi Kerja Pegawai yang menyebutkan bahwa pegawai pemerintah sudah seharusnya memiliki rasa tanggung jawab yang tinggi serta memiliki ketelitian dalam melakukan pelayanan yang dibebankan pada institusi tempat dimana ia bekerja.

Masalah lain yang juga mengemuka dalam hal penerapan kode etik kepegawaian dalam pelayanan kenaikan pangkat ini adalah kurangnya sikap menghargai. Dimana masih dijumpai sikap para pegawai yang terkesan acuh tak acuh dalam memberikan pelayanan. Selain pelaksanaan kode etik yang masih bermasalah seperti dalam penjelasan di atas, yang perlu mendapat perhatian disini adalah kurangnya modalitas penerapan etika publik. Misalnya saja dalam hal netralitas pelayanan kenaikan pangkat. Para pegawai dalam melayani kenaikan 
pangkat tersebut masih terkesan memilah-milah dalam bersikap kepada seseorang saat berlangsungnya proses pelayanan kenaikan pangkat. Hal ini menandakan kurangnya penerapan netralitas sebagai modal dalam etika pelayanan kenaikan pangkat.

Berdasarkan berbagai uraian masalah tentang penerapan etika administrasi negara dalam pelayanan kenaikan pangkat di atas. Serta mengacu pada Peraturan Pemerintah Nomor 12 Tahun 2002 tentang Pelayanan Kenaikan Pangkat dan Peraturan Pemerintah Nomor 42 Tahun 2004 tentang Pembinaan Jiwa Korps dan Kode Etik Kepegawaian Pegawai Negeri Sipil. Penulis kemudian tertarik untuk mengadakan penelitian secara mendalam mengenai "Penerapan Etika Administrasi Negara dalam Pelayanan Kenaikan Pangkat di Kantor BKDD Kabupaten Gowa".

Etika merupakan sebuah cabang ilmu yang berbicara mengenai nilai dan norma moral yang menentukan perilaku manusia dalam hidupnya. Sebagai cabang filsafat, etika menekankan pendekatan yang kritis dalam melihat dan menggumuli nilai dan norma moral tersebut serta permasalahanpermasalahan yang timbul dalam kaitan dengan nilai dan moral Burhanuddin (1997: 1).

Lebih lanjut menurut Darmastuti (2007: 35-36), membagi etika sebagai kajian filsafat menjadi dua bagian, yaitu: a) Etika Umum, merupakan prinsip-prinsip moral yang mengacu pada prinsip moral dasar sebagai pegangan dalam bertindak dan menjadi tolok ukur untuk menilai baik buruknya suatu tindakan yang ada didalam suatu masyarakat. b) Etika Khusus, merupakan penerapan moral dasar dalam bidang khusus. Aplikasi dari etika khusus ini misalnya keputusan seseorang untuk bertindak secara etis dalam suatu bidang tertentu baik itu dalam organisasi.

Etika administrasi negara sebagai bagian dari etika khusus memiliki arti dan peranan penting dalam birokrasi atau organisasi publik. Masalah etika dalam birokrasi menjadi keprihatinan yang sangat besar karena perilaku birokrasi mempengaruhi bukan 
hanya dirinya tetapi masyarakat banyak. Selain itu birokrasi juga bekerja atas dasar kepercayaan, karena seorang birokrat bekerja untuk negara dan berarti juga untuk rakyat.

\section{Pemahaman}

etika

administrasi negara bermakna ganda dimana etika administrasi negara merupakan bidang ilmu pengetahuan yang membahas prinsip-prinsip etis (moral) yang mendasari perilaku para aparat birokrasi pemerintahan, khususnya dalam melaksanakan tugas dan wewenangnya. Disamping itu, terdapat pengertian tentang etika administrasi negara sebagai seperangkat nilai yang menjadi acuan atau penuntun bagi tindakan manusia dalam organisasi. Sedangkan Kartasasmita(1997:

menjelaskan bahwa etika administrasi negara sebagai hubungan antara dunia filsafat, nilai dan moral dengan dunia administrasi sebagai dunia keputusan dan tindakan, yaitu bagaimana mengaitkan keduanya, bagaimana gagasan administrasi seperti ketertiban, efisiensi, kemanfaatan, produktivitas dapat menjelaskan etika dalam prakteknya dan bagaimana gagasan-gagasan dasar etika mewujudkan yang baik dan menghindari yang buruk dapat menjelaskan hakekat administrasi.

Etika pelayanan publik adalah suatu cara dalam melayani publik dengan menggunakan kebiasaan-kebiasaan yang mengandung nilai-nilai hidup dan hukum atau norma yang mengatur tingkah laku manusia yang dianggap baik (Menurut Fadillah (2001: 69) dalam lingkup pelayanan publik, etika administrasi publik diartikan sebagai filsafat dan professional standar (kode etik) atau right rules of conduct (aturan berperilaku yang benar) yang sehatursnya dipatuhi oleh pemberi pelayanan publik atau administrasi publik Harbani pasolong(2007: 193).

Adapun masa kenaikan pangkat Pegawai Negeri Sipil adalah sebagai berikut: (a) Masa kenaikan pangkat Pegawai Negeri Sipil ditetapkan pada tanggal 1 April dan 1 Oktober setiap tahun, kecuali kenaiakan pangkat anumerta dan kenaikan pangkat pengabdian; dan (b) Masa kerja untuk kenaikan 
pangkat pertama Pegawai Negeri Sipil dihitung sejak pengangkatan sebagai Calon Pegawai Negeri Sipil (CPNS).

Fokus utama dalam etika pelayanan publik adalah apakah aparatur pelayanan publik telah mengambil keputusan dan berperilaku yang dapat dibenarkan dari sudut pandang etika agar manusia mencapai kehidupan yang baik (Aswar, 2011). Makna modalitas yang paling sesuai dengan konteks etika publik diartikan sebagai prosedur atau syarat-syarat yang memungkinkan norma-norma etika bisa dijalankan atau dihormati yakni akuntabilitas, Transparansi, Netralitas, (Haryatmoko, 2011: 9).

Etika publik adalah bagian dari etika politik. Etika politik didefinisikan sebagai upaya hidup baik (memperjuangkan kepentingan publik) untuk dan bersama orang lain dalam rangka memperluas lingkup kebebasan membangun institusiinstitusi yang lebih adil. Sedangkan menurut Sutor ( kumorotomo, wahyudi, 2011 ) menyebutkan bahwa tiga dimensi etika politik adalah tujuan, sarana, dan aksi politik .

\section{METODE PENELITIAN}

Waktu penelitian ini direncanakan berlangsung selama kurang lebih 2 (dua) bulan. Penelitian ini dilaksanakan di Sekretariat Daerah kabupaten Gowa jalan Mesjid Raya nomor 30 Kelurahan Sungguminasa Kecamatan Somba Opu Kabupaten Gowa sebagai salah satu unsur birokrasi pemerintah di tingkat kabupaten yang secara fungsional bertanggung jawab terhadap terwujudnya sistem birokrasi yang netral dan profesional.

Penelitian ini bermaksud mengetahui bagaimana penerapan nilai-nilai etika administrasi negara dalam pelayanan kenaikan pangkat di BKDD Kabupaten Gowa. Alasan pemilihan lokasi ini didasarkan pada: BKDD Kabupaten Gowa merupakan salah satu unsur birokrasi di tingkat kabupaten yang menangani sistem manajemen kepegawaian, selain itu pertimbangan lain adalah efektifitas, waktu, dana dan kemudahan dalam mengumpulkan data karena lokasi tersebut mudah dijangkau oleh penulis. 


\section{HASIL DAN PEMBAHASAN}

\begin{tabular}{llcr}
\multicolumn{2}{c}{ Penegakan } & Kode & Etik \\
Pegawai & Negeri & Sipil & yang \\
melakukan & pelanggaran & Kode & Etik
\end{tabular}

Pegawai Negeri Sipil dikenakan sanksi moral. Sanksi moral dibuat secara tertulis dan dinyatakan secara tertutup atau secara terbuka oleh Pejabat Pembina Kepegawaian. Pernyataan secara tertutup disampaikan oleh pejabat yang berwenang atau pejabat lain yang ditunjuk dalam ruang tertutup.

Dalam ruang tertutup bahwa penyampaian pernyataan tersebut hanya diketahui oleh Pegawai Negeri Sipil yang bersangkutan dan pejabat yang menyampaikan pernyataan. Dalam penyampaian pernyataan secara tertutup dapat dihadiri oleh pejabat lain yang terkait, dengan catatan bahwa pejabat yang terkait tersebut tidak boleh berpangkat lebih rendah dari Pegawai Negeri Sipil yang bersangkutan.

Hal ini sesuai dengan Peraturan Pemerintah Republik Indonesia Nomor 42 Tahun 2004 pada pasal 7 menyebutkan bahwasanya dalam pelaksanaan tugas kedinasan dan kehidupan sehari-hari setiap Pegawai Negeri Sipil wajib bersikap dan berpedoman pada etika dalam bernegara, dalam penyelenggaraan Pemerintahan, dalam berorganisasi, dalam bermasyarakat, serta terhadap diri sendiri dan sesama Pegawai Negeri Sipil.

Sebagaimana yang telah dijelaskan sebelumnya bahwa unsur kesetiaan terdiri atas sub-sub unsur penilaian diantaranya yaitu: (a) Tidak pernah menyangsikan kebenaran Pancasila baik dalam ucapan, sikap, tingkah laku, dan perbuatan; (b) Menjunjung tinggi kehormatan Negara dan atau Pemerintah, serta senantiasa mengutamakan kepentingan Negara daripada kepentingan diri sendiri, seseorang, atau golongan; dan (c) Tidak menjadi simpatisan/anggota perkumpulan atau tidak pernah terlibat dalam gerakan yang bertujuan mengubah atau menentang Pancasila UndangUndang Dasar 1945, bentuk Negara Kesatuan Republik Indonesia, atau Pemerintah.

Kesetiaan Pegawai Negeri Sipil merupakan salah satu unsur dalam penilaian kinerja yang 
dilakukan secara periodik untuk melihat sejauh mana kesetiaan tersebut mampu mendukung pelaksanaan kinerja pegawai dapat dilihat dari hasil penelitian terkait masalah etika dari segi kesetiaan pegawai di BKDD Kabupaten Gowa, maka dapat diketahui bahwa salah satu tolok ukur kesetiaan para pegawai adalah dengan melihat sejauh mana pelaksanaan tugas jabatan yang disesuaikan dengan rincian tugas, tanggung jawab dan wewenang yang diemban para pegawai dalam kaitannya dengan pemberian pelayanan serta memprioritaskan kepentingan dinas.

Berdasarkan penjelasan oleh beberapa informan di atas terkait penerapan etika dari segi kesetiaan pegawai di Badan Kepegawaian dan Diklat Daerah (BKDD) Kabupaten Gowa, maka dapat disimpulkan bahwa Penegakan Kode Etik Pegawai Negeri Sipil dalam segi kesetiaan sudah cukup baik, Hal ini disebabkan karena terdapat hubungan erat dengan pelaksanaan tugas dan tanggung jawab para pegawai.
Hasil observasi yang dilakukan peneliti selama di lapangan yang menemukan bahwa para pegawai melaksanakan tugas dan tanggung jawabnya berdasarkan pada jabatan, tugas dan wewenangnya. Mereka melakukan pelayanan kepada para pegawai yang membutuhkan data dan informasi terkait penyesuaian jabatan, melakukan penyusunan formasi pegawai, menyelenggarakan konseling kepegawaian, menyelenggaraan penilaian/pengujian dalam rangka deskripsi kompetensi pegawai serta hal-hal lain yang sesuai dengan tugas pokok dan fungsinya sebagaimana yang diatur dalam Peraturan Daerah Nomor 8 tahun 2008.

Tanggung jawab yang dimaksud dalam penelitian ini adalah kesanggupan pegawai Badan Kepegawaian dan Diklat Daerah (BKDD) Kabupaten Gowa untuk menyelesaikan tugas dan pekerjaan terkait pelayanan kenaikan pangkat yang diserahkan kepada para pegawai dengan sebaik baiknya, dapat dilihat berdasarkan hasil yakni salah satu bentuk tanggung jawab 
yang dapat dilihat adalah apabila para pegawai pada masing-masing bidang mampu melaksanakan dan menyelesaikan setiap pekerjaan yang diberikan kepadanya dengan baik dan benar serta mampu menerapkan pelayanan secara profesional dan berkualitas.

Beberapa hasil informan dapat dilihat bahwa penerapan kode etik pegawai di kantor BKDD Kabupaten Gowa sudah cukup baik. Hal ini dapat terlihat dari pekerjaan yang dilakukan dengan baik dan benar, tepat waktu serta pelayanan yang diberikan kepada masyarakat secara sopan dan profesional.

Hasil observasi peneliti selama di lapangan yang jga menemukan bahwa para pegawai pada BKDD Kabupaten Gowa mampu melaksanakan setiap tugas yang diberikan kepadanya secara baik dan benar, baik dari segi ketepatan waktu pekerjaan, dan penyusunan laporan serta pelaksanaan rencaa kerja yang mereka buat. Selain hal tersebut, pemberian pelayanan kepada para pegawai maupun kepada masyarakat yang membutuhkan data dan informasi terkait formasi dan seleksi calon pegawai juga dilaksanakan dengan baik dan profesional tanpa melakukan diskriminasi kepada pribadi maupun golongan.

Jika melihat secara realita pelaksanaan tanggung jawab para pegawai dalam melaksanakan tugas dan pekerjaan yang diembannya telah sesuai dengan paparan visi dan misi yang telah ditetapkan oleh Badan Kepegawaian dan Diklat Daerah (BKDD) Kabupaten Gowa. Selain hal tersebut, para pegawai dari berbagai bidang tugasnya senantiasa mempersipakan diri mereka untuk sewaktu-waktu dievaluasi terutama dalam hal pencapaian kinerja yang dilakukannya selama ini.

Ketaatan dapat diartikan sebagai kesanggupan pegawai Badan Kepegawaian dan Diklat Daerah (BKDD) Kabupaten Gowa untuk menaati segala peraturan perundangundangan, peraturan kedinasan yang berlaku, dapat diketahui bahwa kesadaran para pegawai yang bertugas di Badan Kepegawaian dan Diklat Daerah (BKDD) Kabupaten Gowa dalam mentaati etika pegawai serta peraturan-peraturan kedinasan 
yang diterapkan sudah cukup baik dan terarah. Ditambahkan oleh informan bahwa hal ini dikarenakan para pegawai tersebut telah mengikuti berbagai macam proses pendidikan dan pelatihan serta seminar yang merupakan sebuah kebutuhan kedinasan sehingga sikap dan perilaku para pegawai tercermin dari sejauh mana mereka melaksanakan tugas dan tanggung jawabnya secara efektif dan efisien.

Kesadaran pegawai untuk mentaati etika pegawai serta peraturan kedinasan yang ada sudah cukup baik sehingga sikap dan perilakunya dapat tercermin dari pelakasanaan tugas yang diberikan kepadanya. Namun, terkadang tingkat ketaatan pegawai juga harus dibarengi dengan pengawasan atau kontrol secara berkelanjutan dengan tujuan agar kinerja pegawai dapat dilaksanakan dengan baik dan benar sebagaimana peraturan yang telah ditetapkan.

Observasi peneliti selama dilapangan yang menemukan bahwa terdapat perbedaan sikap dan perilaku para pegawai yang telah mengikuti berbagai pendidikan dan pelatihan kedinasan dengan pegawai yang belum atau masih kurang mengikuti berbagai pelatihan kedinasan.

Hal ini dapat dilihat dari kinerja yang mereka lakukan termasuk di dalamnya efektivitas dan efisiensi kerja, penyusunan laporan dan yang lebih utama adalah pengambilan keputusan terkait pekerjaan yang dihadapinya, pemberian layanan baik kepada sesama pegawai maupun masyarakat, dan ketaatan mereka dalam mengikuti berbagai aturan yang ditetapkan.

Makna modalitas yang paling sesuai dengan konteks etika publik diartikan sebagai prosedur atau syarat-syarat yang memungkinkan norma-norma etika bisa dijalankan atau dihormati. Modalitas dalam penelitian dapat diartikan sebagai sarana relasi yang harus dipatuhi seperti transparansi, akuntabilitas dan netralitas pegawai BKDD Kabupaten 
Gowa dalam pelayanan kenaikan pangkat.

Akuntabilitas merupakan perwujudan kewajiban suatu instansi pemerintah untuk mempertanggung jawabkan keberhasilan dan kegagalan pelaksanaan misi organisasi penjelasan dari informan modalitas etika pegawai sangat berkaitan erat dengan akuntabilitas pegawai baik dalam bentuk kewajiban dalam melaksanakan tugas pokoknya maupun dalam penyusunan laporan kinerja yang dilakukannya.

Adapun penjelasan dari beberapa informan terkait modalitas etika publik dalam hal ini akuntabilitasnya, maka peneliti menyimpulkan bahwa wujud akuntabilitas pada Badan Kepegwaian dan Diklat Daerah (BKDD) Kabupaten Gowa sudah terlaksana dengan cukup baik.

Hal ini dikarenakan akuntabilitas pegawai berkaitan erat terhadap proses kenaikan pangkat para pegawai yang dilihat berdasarkan capaian kinerja dan pelaporan yang dibuatnya secara transparan dan obyektif, . Selain itu, untuk meminimalisir terjadi berbagai bentuk diskomunikasi, kesalahpahaman dan asumsi negatif diantara para pegawai.

Observasi yang dilakukan oleh peneliti selama di lapangan yang menemukan bahwa kenaikan pangkat para pegawai khususnya di lingkup Badan Kepegawaian dan Diklat Daerah (BKDD) Kabupaten Gowa telah berjalan sebagaimana mestinya.

Hal ini dapat dilihat dari proses pelaksanaan kenaikan pangkat para pegawai yang dilihat berdasarkan kinerjanya selama menjabat/memangku sebuah jabatan yang diembannya, hal sistem kinerja pada bidang perencanaan dan pelaporan lebih memfokuskan kepada pencapaian sasaran yang berhubungan dengan perencanaan pegawai. Hanya saja masih terdapat beberapa pegawai yang kurang memahami bagaimana sebenarnya prosedur yang dijalankan terkait pengukuran kinerja dari segi akuntabilitasnya yang pada gilirannya dapat memberikan peluang kepada pegawai tersebut dalam hal kenaikan pangkat 
Transparansi harus dibangun dalam rangka kebebasan aliran informasi. Transparasi adalah nilai utama dari akuntabilitas, dimana individu atau organisasi dikatakan akuntabel apabila ia mampu menjelaskan atau menilai tindakan atau aksinya. dapat diketahui bahwasanya segala bentuk kegiatan yang dilakukan oleh Badan Kepegawaian dan Diklat Daerah (BKDD) Kabupaten Gowa senantiasa ditransparansikan kepada seluruh pegawai baik yang berada pada lingkup sekretariat daerah atau diluar dari lingkup sekretariat terutama dalam hal pemberian informasi kenaikan pangkat.

pemberian layanan yang diberikan oleh pihak Badan Kepegawaian dan Diklat Daerah (BKDD) Kabupaten Gowa kepada para masyarakat sudah cukup baik.

Hal ini berdasarkan pada keterangan oleh informan yang menjelaskan bahwa pelayanan yang diberikan tersebut sopan dan ramah, senantiasa bersikap terbuka terhadap berbagai informasi yang dibutuhkan sambil menjelaskan mekanisme/prosedur yang harus dilalalui oleh masyarakat atau pegawai.

Sistem transparansi yang dilakukan di Badan Kepegawaian dan Diklat Daerah (BKDD) Kabupaten Gowa sudah mampu dijalankan dengan cukup baik. Hal ini dapat dilihat dari adanya sistem aplikasi pelayanan kepegawaian (SAPK) yang dilakukan oleh BKDD. Kabupaten Gowa dengan harapan agar para pegawai dan masyarakat yang ingin memperoleh informasi terkat mengenai kenaikan pangkat, formasi pegawai dan pelaksanaan mutasi dan informasi yang terkait dengan kepegawaian dapat diperoleh dengan mudah melalui penyediaan akses berbasis online tersebut. Hanya saja pada segi kedisiplinan waktu belum mampu dijalankan secara optimal, hal ini disebabkan oleh adanya beberapa oknum yang terkadang pulang kerja belum pada waktu yang telah ditentukan sehingga dapat menjadi faktor penghambat dalam pemberian pelayanan kepada para pegawai dan masyarakat yang membutuhkan.

Netralitas ini berupa tuntutan yang terkait dengan keseluruhan 
program agar memenuhi kewajiban kebutuhan warga Negara tanpa diskriminasi, sedangkan kalau terkait dengan media berarti harus ada objektivitas informasi. Netral berarti operator pelayanannya tidak memihak. Netralitas yang dimaksud dalam penelitian ini adalah: (a) Netralitas sebagai sarana yang memungkinkan umtuk memberi prioritas daalam pelayanan kenaikan pangkat di BKDD kabupaten gowa tidak hanya pada sekelompok golongan saja; (b) Netralitas dalam penelitian ini juga terkait dengan keseluruhan program dalam pelayanan kenaikan pangkat di BKDD Kabupaten Gowa agar tidak ada diskriminasi dalam pelayanan.

Dapat diketahui bahwa setiap pegawai khususnya di Badan Kepegawaian dan Diklat Daerah (BKDD) Kabupaten Gowa senantiasa diberikan keleluasaan untuk beraktualisasi dalam menyelesaikan setiap tugas dan tanggung jawabnya, hasil observasi peneliti selama di lapangan yang menemukan bahwa dalam proses kenaikan pangkat para pegawai pihak BKDD Kabupaten Gowa bekerja sama dengan BAPERJAKAT melakukan proses penilaian dan evaluasi seobyektif mungkin untuk kemudian hasil laporan penilaian tersebut diserahkan kepada Bupati selaku pembina kepegawaian di tingkat daerah.

Hasil observasi peneliti selama di lapangan yang menemukan bahwa dalam proses kenaikan pangkat para pegawai pihak BKDD Kabupaten Gowa bekerja sama dengan BAPERJAKAT melakukan proses penilaian dan evaluasi seobyektif mungkin untuk kemudian hasil laporan penilaian tersebut diserahkan kepada Bupati selaku pembina kepegawaian di tingkat daerah.

Namun terkadang hasil dari penilaian dan evaluasi laporan tersebut terkadang diputuskan/ditentukan oleh seorang Bupati secara sepihak tanpa meminta saran dari pihak BKDD dan BAPERJAKAT berdasarkan beberapa pertimbangan tertentu termasuk di dalamnya pertimbangan politik. Hal inilah yang terkadang mengakibatkan kekecewaan diantara para pegawai dan menimbulkan 
penurunan prestasi kerja para pegawai.

Dapat diketahui bahwa pemberian pelayanan yang diberikan oleh para pegawai di lingkup Badan Kepegawaian dan Diklat Daerah (BKDD) Kabupaten Gowa menurut informan belum profesional. Hal ini dilandasi dengan temuan oleh informan yang menjelaskan bahwa terkadang para pegawai bersikap diskriminatif atau membeda-bedakan bentuk pelayanan kepada masyarakat terutama jika yang dilayani tersebut merupakan bagian dari keluarga/kerabatnya sendiri.

Maka dapat disimpulkan bahwa netralitas dalam hal kenaikan pangkat kepada para pegawai belum berjalan dengan baik termasuk netralitas pegawai dalam pemberian layanan baik antara pegawai itu sendiri khususnya kepada masyarakat. Dari segi kenaikan pangkat pegawai terkadang pengambilan keputusan kenaikan pangkat tidak obyektif dan terkesan bersifat sepihak hal ini disebabkan karena Bupati selaku Pembina kepegawaian di tingkat daerah kurang berkoordinasi dengan pihak dari BKDD dan BAPERJAKAT selaku pihak yang berwenang dalam proses evaluasi dan penilaian kinerja pegawai selain itu hal ini juga disebabkan oleh beberapa pertimbangan politik dari seorang Kepala Daerah sehingga menimbulkan kekecewaan kepada para pegawai yang memiliki kinerja yang baik dan benar.

\section{KESIMPULAN}

Berdasarkan hasil penelitian yang dilakukan di Badan Kepegawaian dan Diklat Daerah (BKDD) Kabupaten Gowa mengenai Penerapan Etika Administrasi Negara dalam Pelayanan Kenaikan Pangkat di Badan Kepegawaian dan Diklat Daerah (BKDD) Kabupaten Gowa. Maka dari itu, penulis dapat menyimpulkan dari hasil penelitian yaitu 1) Penerapan kode etik kepegawaian baik dari segi kesetiaan, tanggung jawab dan ketaatan para pegawai di Badan Kepegawaian dan Diklat daerah sudah dijalankan dengan cukup baik. Hal ini dapat dilihat pada: (a) Kesetiaan, dalam hal ini didasarkan pada pelaksanaan tugas dan tanggung 
jawab para pegawai yang dijalankan dengan baik dan rincian tugas yang disesuaikan dengan jabatan masingmasing dapat diterapkan secara optimal; (b) Tanggung jawab, hal ini didasarkan pada pekerjaan yang dilakukan dengan baik dan benar, tepat waktu serta pelayanan yang diberikan kepada masyarakat secara sopan dan profesional; (c) Ketaatan, hal ini didasarkan pada kesadaran pegawai untuk mentaati etika pegawai serta peraturan kedinasan yang ada sehingga sikap dan perilakunya dapat tercermin dari pelakasanaan tugas yang diberikan kepadanya. 2) Penerapan modalitas etika publik dalam pelayanan kenaikan pangkat di Kantor BKDD Kabupaten Gowa dari segi akuntabilitas sudah cukup baik, hal ini didasarkan pada capaian kinerja dan pelaporan yang dibuatnya secara transparan dan obyektif. Walaupun masih terdapat ketidaksesuaian antara pegawai yang diberikan kenaikan pangkat dengan kinerja yang dilakukannya, sebab terkadang pegawai yang menerima kenaikan pangkat dipengaruhi oleh pendekatan politik,

\section{Daftar pustaka}

Haris, Abdul. 2007. Sidoarjo. Pengantar Etika Islam. AlAfkar:

Peraturan Pemerintah Nomor 46 Tahun 2011 Tentang Penilaian Prestasi Kerja Pegawai.

Keputusan Kepala Badan Kepegawaian Negara Nomor 12 Tahun 2002 tentang Kenaikan Pangkat Pegawai Negeri Sipil

Peraturan Pemerintah Nomor 42 Tahun $2004 \quad$ tentang Pembinaan Jiwa Korps dan Kode Etik Pegawai Negeri Sipil.

Burhanuddin, Salam. 1997. Jakarta .Etika Sosial. Rineka Cipta.

Darmastuti, Rini. 2007. Yogyakarta. Etika PR dan E-PR. Gava Media.

Haryatmoko. 2011. Jakarta .Etika Publik. Gramedia Pustaka Utama:

Kartasasmita, Ginanjar. 1997. Jakarta. Administrasi Pembangunan. LP3ES.

Aswar. 2011. Etika Pelayanan Publik. Sumber: http://aswark.blogspot.co.id/, di akses pada tanggal 16 Maret 2016 pada pukul 20.15 Wita. 
Pasolong, Harbani. 2007. Bandung. Teori Administrasi Publik. Alfabeta.

Kumorotomo, Wahyudi. 2011.

Jakarta Etika Administrasi Negara. PT RajaGrafindo. Persada.

Fadillah, Putra. 2001. Yogyakarta Paradigma Kritis dalam Studi Kebijakan Publik. Pustaka Pelajar Offset. 